\title{
Suitability of Soft Clay as Clay Liner based on Clay-Leachate Interaction Studies
}

\author{
Sandhya Rani. R. ${ }^{1}$, Shiva Chandra. V. ${ }^{2}$ \\ ${ }^{\text {I}}$ (Associate Prof., Dept. of Civil Engg, MVSR Engg. College, Hyderabad, India, \\ ${ }^{2}$ (Assistant Prof., Dept. of Civil Engg, MVSR Engg. College, Hyderabad, India,
}

\begin{abstract}
Waste Disposal in urban areas with dense population is a challenging problem for a developing country like India. Although there are other methods for waste disposal (Recycling, Composting, Incineration), it is generally accepted that landfill is the most cost effective disposal method. This has the advantage of putting useless land to reclamation. Previous studies shown that clay compacted to a permeability of less than $10^{-7} \mathrm{~cm} / \mathrm{sec}$ form a good barrier to leachate and also cost effective. The present work in this area has two aspects viz., suitability of local soils from stability and permeability characteristics for use as landfill clay liners and study on clay-leachate interaction using soft clay as clay liner. The basic properties like Liquid limit (LL), Plastic limit (PL), Free swell index (FSI) and $\mathrm{pH}$ are discussed in terms of physicochemical aspect. Certain mineralogical and microstructure studies undertaken on this interaction phenomenon are also presented. It is concluded that organic chemicals presented in the leachate destroy the double layer properties of soft clay and reduce the plasticity of the soils. Formations of some new clay minerals are observed in X-ray Diffraction graphs and formation of aggregates and flocs are observed in scanning electron micrographs.
\end{abstract}

Keywords: Landfill, Leachate, Permeability, Scanning Electron microscope, X-ray Diffraction.

\section{Introduction}

The main objectives in carrying out this study is to review the geotechnical and environmental aspects of landfills and landfill design, to understand the effect of leachate with curing on the physical and physico-chemical properties of soil like LL, PL, Shear Strength and $\mathrm{pH}$, on mineralogical variations through $\mathrm{X}$-ray diffraction analysis and on fabric changes through Scanning electron microscope. In the present investigation, studies have been carried out on 10 locally available soils in and around Visakhapatnam to check their suitability as a clay liner depending upon their PI and clay fraction.

Low permeability clays along with synthetic liners are generally used as a barrier between the waste and the sub soil to contain leachate. In general clay soils having permeability less than $10^{-7} \mathrm{~cm} / \mathrm{sec}$ are used for landfill liners. In this study soft clay is chosen for the analysis as clay liners. Tests have been carried out on soft clay obtained from Airport area, Visakhapatnam. The soft clay contaminated with municipal solid waste leachate collected from dumping area, Madhuravada, Visakhapatnam. Atterberg limits, free swell index and vane shear strength have been determined over a curing period. The soil specimens have been analyzed for physico-chemical changes such as $\mathrm{pH}$ value and exchangeable cations. The X-ray diffraction and scanning electron microscope studies on uncontaminated and contaminated soil specimens have been carried out at the Central Instruments Laboratory, University of Hyderabad. These studies have been utilized to assess the changes in mineralogy and the microstructure of soft clay due to leachate contamination.

\section{Background Information}

The term "Landfill" is used to describe a containment system, which separates the waste from the surrounding environment. This system mainly used for final disposal of municipal solid waste on land, designed and constructed with the objective of minimum impact to the environment. Landfill design philosophy in the early 1990's tended towards total containment and isolation. It is now recognized that this is unattainable and that it is more appropriate to design for controlled release rather than attempting to indefinite isolation. The basic philosophy of all modern landfills revolves around the concept that waste which will not become stable or inert with time will be treated as "Stored" and not "Disposed".

Waste containment can be effected through engineered design in which a basal lining system and a cover system isolates the waste dump from the hydrological cycle, Leachate collection system and gas collection system collects the products of reactions inside a waste dump and measures adopted to minimize factors such as wind and water erosion, pests, rodents etc. A waste containment facility so designed and constructed is termed as an "Engineered Landfill". In a tropical country like India at high temperatures complex biochemical reactions takes place with waste decomposition that may lead to increased $\mathrm{pH}$ releasing products of decomposition in both liquid and gaseous form. Landfill gas consists of Methane, Carbon Dioxide 
with presence of Hydrogen. It is important to control within a landfill site using interceptor and collector drains to prevent it travelling through the ground. Similarly, the leachate needs to be contained and collected to prevent pollution of the ground and groundwater. The rainwater essentially permeates the decaying waste organic products and soluble waste constituents are leached out. Their harmful products are contained within the site by encapsulating the refuse with a liner along the base and the sides. The most common landfill lining material is a clay soil (in a low permeable state) with or without the use of membrane synthetic liners. The later is specifically used with low permeable clay layers to provide an additional barrier in case of leakage [1].

\section{Clay Liners}

The clay liner whilst acting as a barrier can also act as a chemical filter so that the emerging liquid has the harmful substances removed. It is not known whether prolonged contact between leachate and the clay can cause some detrimental affect either by increasing its permeability or by making it brittle. The specifications for a clay liner include a thickness of at least one meter and a permeability of $10^{-6} \mathrm{~mm} / \mathrm{sec}$. They also indicate that absence of shrinkage cracks and clods in compacted layer, adequate strength for stability under compressive loads as well as along slopes and minimal influence of leachate on permeability. Although there are many suggestions on material specifications such as clay content between 18 and $25 \%$, percentage fines between 40 and $50 \%$, liquid limit between 25 and 30\%, plasticity index between 10 and $30 \%$. In spite of the fact that specifications cover a wide range it is often difficult to find a natural soil satisfying all specifications including permeability. From the literature available, it is observed that only concentrated organic chemicals in leachate can attack compacted clay, effectively destroying the barrier characteristics of the liner material over a period of time. Hence there is no immediate indication of soil potential for liner characteristics. Keeping in view the above constraints, it is proposed to study the long term effect of leachate on clay liners.

\section{Mineralogy and Microstructure X-ray Diffraction (XRD)}

The most widely used method for identification of clay minerals and the study of their crystal structure is from an X-ray diffraction pattern of a powdered sample of the clay size fractions of a soil. X-ray has wavelengths in the range of 0.01 to $100 \mathrm{~A}^{\mathrm{o}}$. The minerals present can usually be identified from diffraction lines, although it may be difficult to specify the proportions of each mineral in a mixture. Interpretation of diffraction pattern is based on the the crystal structure of clay. The shape and size of the crystal particle exposed to X-ray influencing the diffraction effects. The orientation of parallel atomic planes, relative to the direction of the incident beam, at which radiations are in phase, depends on the wavelength of the $\mathrm{X}$-rays and the spacing between atomic planes. Bragg law forms the basis for identification of crystals using X-ray diffraction. Since no two minerals have the same spacing of inter atomic planes in three dimensions, the angles at which diffraction occurs are used for identification. X-ray diffraction is particularly well suited for clay minerals because the spacing is characteristic for each clay mineral group. The basal planes generally give the most intense reflections of any planes in the crystal because of the close packing of atoms in these planes.

Quantitative determinations of the different minerals in a soil on the basis of simple comparison of diffraction peak heights or areas cannot be made because of differences in mass absorption coefficients of different minerals, in particle orientations, in sample weights, in surface texture of the sample, in crystallinity of the minerals, in hydration, and in other factors. In some cases, estimates based on X-ray data alone are at best semi-quantitative.

\section{Scanning Electron Microscope (SEM)}

The use of the electron microscope has permitted the precise determination of the shape of the particles of various clay minerals and has shed light on the range of particle size of the components of clay and on the degree to which the particle size can be reduced when the clay is worked mechanically with water. Numerous investigators have published electron micrographs of the clay minerals and discussed electron microscopic techniques as applied to clay mineral researches. It is convenient to describe fabric features in terms of the form and function of the units. In electron microscopy, the image formation is due to the scattering of electrons as the electron beam passes through the sample. In the techniques available, the electron microscope is the only one that can reveal particles and particle arrangements directly. The practical limit of resolution using the SEM is about $100 \mathrm{~A}^{\mathrm{o}}$; thus detail at the individual particle level is easily seen. The main difficulty in the use of the electron microscope for study of the fabric is the preparation of the sample surfaces, surface replicas, or ultra thin sections that retain the undisturbed fabric of the original sample, the greater the likelihood of disturbance, Soils containing expansive clay minerals may also pose problems because removal of interlayer water may cause undetected changes in micro fabric, or there may be excessive shrinkage. The dry fracture -peel technique appears the best of the available alternatives. 


\section{Materials And Methods}

Ten soil samples are collected from different areas of Visakhapatnam for study of clay liner suitability. The municipal solid waste leachate was obtained from waste dumping area, Madhuravada, Visakhapatnam. The soft clay used for the study of soil-leachate interaction was obtained from Airport area, Visakhapatnam (at $2 \mathrm{~m}$ depth from the ground level).

\section{Experimental Programme}

It was proposed to carry out the investigation in three stages. In the first stage, 10 locally available soils have been analyzed for their geotechnical properties and checked whether they are suitable for clay liners or not according to their PI and clay fraction. In the second stage, the soft clay has been analyzed for various geotechnical parameters including physico-chemical changes, mineralogical analysis and microstructure analysis. In the third stage, the soft clay has been mixed with various proportions of leachate viz., $10 \%, 20 \%$, and $40 \%$ and tests have been conducted at 10 days, and 40 days of curing period.

\section{Procedure for evaluating soil-leachate interactions}

Soft clay passing through $425 \mu$ IS sieve was mixed with various proportions of leachate say $10 \%$, $20 \%$ and $40 \%$ by weight and water at natural moisture content. This composite material was left for varying exposure periods of 10 days and 40 days. To reduce the problem of moisture evaporation, the samples were packed in thick polythene bags and placed in a water bath for a specified curing period. At the end of the specified period, tests were performed on the samples for finding out the changes in physico-chemical properties and strength.

\section{Sample preparation for fabric analysis}

Study using X-ray diffraction and Scanning electron microscope requires that the pore fluid be removed or replaced. Air-drying may be suitable for stiff soils, partly saturated soils, and the soils that do not undergo significant shrinkage. For soft samples at high water content, oven drying may cause less change in fabric than air drying, evidently because the relatively long time needed for air drying allows for greater particle rearrangement [2]. On the other hand, the stresses induced during oven drying may result in some particle breakage. Initially the soil mix was oven dried and powdered to very fine form. The powdered soil was sieved through $75 \mu$ IS sieve and the same was tested for XRD and SEM.

\section{Results And Discussions}

Ten samples were tested for basic properties, strength, compaction and permeability. The properties of ten different soils in and around Visakhapatnam are furnished in Table 1. The permeability was estimated from the Allen Hazen's equation $\left(\mathrm{k}=\mathrm{CD}_{10}{ }^{2}\right)$. However, for soil-leachate interaction studies, soft clay in view of its typical chemical and saline extremities is selected. Soft clay available all along the coast and a highly problematic soil in Visakhapatnam, though low in strength, satisfies the permeability criteria if compacted properly. The presence of sulphates, chlorides, carbonates and chlorites present in soft clay are thought to provide some useful information on basic properties like LL, FSI, pH and on mineralogical variations and microstructure. The physical and chemical properties of soft clay and chemical composition of leachate are shown in Table 2 to 4.

\section{Suitability of ten soils as clay liners}

The hydraulic conductivity is controlled primarily by clay content alone [3]. Depending on the liner specifications given by various researchers, the fines percentage is in between 40 and $50 \%$, plasticity index is in between 10 and $30 \%$ and the ratio of plasticity index to clay content is greater than or equal to 0.3 . According to this plasticity index, the sandy clay, silty clay (MVP), Silty clay (EP colony) and expansive clay are suitable for liner construction. The ratio of plasticity index to clay content of soils is in suitable limits for sandy clay, silty clay (MVP), silty clay (EP colony), expansive clay, marine clay and soft clay. The liner material in normally expected to fulfil the requirement of hydraulic conductivity of $10^{-7} \mathrm{~cm} / \mathrm{sec}$ or less. The soils, silty clay (EP colony), expansive clay, marine clay and soft clay can meet the hydraulic conductivity requirements. Clay with smaller particles i.e., having larger specific surface area and thicker double layers, combine to enhance the tortuosity experienced by the permeating fluid, resulting in low permeability [4]. Finally taking all these aspects into consideration, one can conclude that, the soils namely sandy clay, silty clay (EP colony) and expansive clay can meet the three requirements i.e, plasiticity index, clay fraction and permeability of clay liners and may be used as a good barrier materials. Although, the compaction of marine clay and soft clay in the field is difficult, it can meet the primary requirements (clay fraction and hydraulic conductivity) of clay liners and perform as a good liner material. Sandy clay and silty clay (MVP) meet the plasticity and clay content requirements and used as a liner material along with suitable additives. The rest of 
the soils namely silty sand, dune fine sand, gravelly clay, red silty soil and clayey sand cannot be used as liner material in landfill construction without a suitable and adequate stabilizing agent.

\section{Liquid Limit behaviour}

Many organic chemicals tend to shrink the diffuse double layer that surrounds clay particles [5]. Effect of organic chemicals on liquid limit behaviour of soil was studied by Nirmala Gnanapragasam et al [6]. According to Nirmala Gnanapragasam, the leachate-contaminated samples had lost its cohesive nature, possibly due to the collapse of the double layer in the presence of organic chemicals. In contrast, uncontaminated samples remained intact. It is possible that the organic chemicals adsorbed onto the surface of clay, decreased the thickness of the double layer, by decreasing the extent of water adsorption, and resulted in lower liquid limit. Variation of liquid limit with different percentages of leachate for 10 and 40 days curing period is furnished in Fig. 1.

\section{Plastic Limit behaviour}

The low dielectric constant of organic chemicals is responsible for reducing the double layer thickness [7]. The organic chemicals reduced or eliminated the plasticity of the soils [8]. Clay behaves like as less plastic material in the presence of leachate. The dielectric constant of the leachate may be low and these results in a smaller thickness of the double layer compared to that in water, making the clay less plastic. The leachate contaminated samples lost this integrity due to the decreased thickness of double layer. Variation of plastic limit with different percentages of leachate for different curing periods is given in Fig. 2. The variations in plasticity index values are shown in Fig. 3. As liquid limit and plastic limit values are correspondingly increased there is no change in plasticity index values. The changes in liquid limit, plastic limit and plasticity index values in leachate contaminated soils are given in Table 5.

\section{Effect of pH}

The $\mathrm{pH}$ value of leachate is much higher than the $\mathrm{pH}$ value of soil. The presence of organic matter, iron oxide, aluminium oxide, chlorides and sulphates are responsible for lower $\mathrm{pH}$ value of soft clay and calcium, magnesium, sodium and potassium are responsible for higher $\mathrm{pH}$ value of leachate. When leachate is mixed with soil, the oxides and organic matter present in the soil are dissolved in leachate and increases the $\mathrm{pH}$ value of soil. This increases the fertility of soil advantageous for vegetation growth that arrest active seepage. Variation of $\mathrm{pH}$ with increasing percentages of leachate for 10 and 40 days curing period are furnished in Fig. 4.

Table 1: Properties of ten different soils in and around Visakhapatnam

\begin{tabular}{|c|c|c|c|c|c|c|c|c|c|c|c|c|c|c|}
\hline \multirow{2}{*}{$\begin{array}{c}\text { S.N } \\
\text { o }\end{array}$} & \multicolumn{4}{|c|}{ Grain Size } & \multicolumn{3}{|c|}{ Consistency } & \multirow{2}{*}{$\begin{array}{c}\text { IS } \\
\text { Sym } \\
\text { bol }\end{array}$} & \multirow{2}{*}{$\begin{array}{c}\gamma \\
(\mathrm{g} / \mathrm{c} \\
\mathrm{c})\end{array}$} & \multirow{2}{*}{$\begin{array}{c}\mathrm{C} \\
(\mathrm{t} / \mathrm{m} \\
2)\end{array}$} & \multirow{2}{*}{$\begin{array}{l}\varphi \\
(\mathrm{d} \\
\mathrm{eg} \\
)\end{array}$} & \multirow{2}{*}{$\begin{array}{c}\text { SB } \\
\text { C } \\
(\mathrm{t} / \mathrm{m} \\
2)\end{array}$} & \multirow{2}{*}{$\begin{array}{c}\mathrm{k} \\
(\mathrm{mm} / \mathrm{sec})\end{array}$} & \multirow[t]{2}{*}{ Type of Soil } \\
\hline & $\begin{array}{c}\text { Grave } \\
1 \\
(\%)\end{array}$ & $\begin{array}{c}\text { San } \\
\text { d } \\
(\%)\end{array}$ & $\begin{array}{l}\text { Silt } \\
(\%)\end{array}$ & $\begin{array}{c}\text { Cla } \\
\mathrm{y} \\
(\%)\end{array}$ & $\begin{array}{l}\text { LL } \\
(\% \\
)\end{array}$ & $\begin{array}{l}\text { PL } \\
(\%)\end{array}$ & $\begin{array}{c}\text { PI } \\
(\%)\end{array}$ & & & & & & & \\
\hline 1 & 0 & 35 & 38 & 27 & 34 & 17 & 17 & $\mathrm{CL}$ & $\begin{array}{c}1.8 \\
6\end{array}$ & 3.0 & 30 & $\begin{array}{l}41 . \\
62\end{array}$ & $\begin{array}{c}1.6 \times 10- \\
6\end{array}$ & $\begin{array}{c}\text { Sandy Clay } \\
\text { (MVP } \\
\text { Colony) }\end{array}$ \\
\hline 2 & 0 & 29 & 41 & 30 & 41 & 21 & 20 & CI & $\begin{array}{c}1.8 \\
4\end{array}$ & 4.0 & 28 & $\begin{array}{c}44 . \\
01\end{array}$ & $\begin{array}{c}1.6 \times 10- \\
6\end{array}$ & $\begin{array}{l}\text { Silty Clay } \\
\text { (MVP } \\
\text { Colonv) }\end{array}$ \\
\hline 3 & 0 & 9 & 51 & 40 & 53 & 27 & 26 & $\mathrm{CH}$ & $\begin{array}{c}1.7 \\
8\end{array}$ & 7.0 & 11 & $\begin{array}{l}28 . \\
83\end{array}$ & $\begin{array}{c}4.0 \times 10- \\
7\end{array}$ & $\begin{array}{l}\text { Silty Clay } \\
\text { (EP Colony) }\end{array}$ \\
\hline 4 & 0 & 11 & 49 & 40 & 49 & 25 & 24 & $\mathrm{CH}$ & $\begin{array}{c}1.7 \\
9\end{array}$ & 5.5 & 12 & $\begin{array}{l}24 . \\
89\end{array}$ & $\begin{array}{c}4.0 \times 10- \\
7\end{array}$ & $\begin{array}{c}\text { Expansive } \\
\text { Clay } \\
\text { (Sheelanagar) }\end{array}$ \\
\hline 5 & 0 & 5 & 52 & 43 & 75 & 35 & 0 & $\mathrm{CH}$ & $\begin{array}{c}1.6 \\
0\end{array}$ & 2.5 & 0 & $\begin{array}{c}5.0 \\
0\end{array}$ & $\begin{array}{c}9.0 \times 10- \\
7\end{array}$ & $\begin{array}{l}\text { Soft Marine } \\
\text { Clay } \\
\text { (Port Area) }\end{array}$ \\
\hline 6 & 0 & 48 & 42 & 10 & 19 & NP & NP & SM & $\begin{array}{c}1.8 \\
8\end{array}$ & 0.0 & 34 & $\begin{array}{l}26 . \\
69\end{array}$ & $\begin{array}{c}4.0 \times 10- \\
5\end{array}$ & $\begin{array}{l}\text { Silty Sand } \\
\text { (Kirlampudi) }\end{array}$ \\
\hline 7 & 0 & 90 & 10 & 0 & - & $\mathrm{NP}$ & NP & SP & $\begin{array}{c}1.7 \\
5\end{array}$ & 0.0 & 30 & $\begin{array}{l}17 . \\
71\end{array}$ & $\begin{array}{c}5.6 \times 10- \\
2\end{array}$ & $\begin{array}{c}\text { Dune Fine } \\
\text { Sand } \\
\text { (Rushikonda) }\end{array}$ \\
\hline 8 & 52 & 20 & 10 & 18 & 20 & 15 & 5 & GC & $\begin{array}{c}1.8 \\
9\end{array}$ & 5.0 & 32 & $\begin{array}{l}66 . \\
02\end{array}$ & - & $\begin{array}{c}\text { Gravelly Clay } \\
\text { (Madhavadhar } \\
\text { a) }\end{array}$ \\
\hline 9 & 0 & 20 & 70 & 10 & 20 & NP & NP & SM & $\begin{array}{c}1.8 \\
0\end{array}$ & 1.0 & 26 & $\begin{array}{l}19 . \\
92\end{array}$ & $\begin{array}{c}4.0 \times 10- \\
5\end{array}$ & $\begin{array}{l}\text { Red Silty Soil } \\
\text { (AU Campus) }\end{array}$ \\
\hline 10 & 0 & 32 & 40 & 28 & 24 & 16 & 8 & $\mathrm{CL}$ & $\begin{array}{c}1.8 \\
6\end{array}$ & 3.8 & 29 & $\begin{array}{l}45 . \\
25\end{array}$ & $\begin{array}{c}1.6 \times 10- \\
6\end{array}$ & $\begin{array}{l}\text { Clayey Sand } \\
\text { (Pandu } \\
\text { rangapuram) }\end{array}$ \\
\hline
\end{tabular}


Table 2: Properties of Soft Clay

\begin{tabular}{|c|c|c|}
\hline S.No & Description & Value \\
\hline & Grain Size Analysis & $46 \%$ \\
1 & Clay & $37 \%$ \\
& Silt & $17 \%$ \\
\hline 2 & Sand & $69 \%$ \\
\hline 3 & Liquid Limit & $33 \%$ \\
\hline 4 & Plastic Limit & $36 \%$ \\
\hline 5 & Plasticity Index & $\mathrm{CH}$ \\
\hline 6 & IS Classification & 2.54 \\
\hline 7 & Specific gravity & $2.0 \mathrm{~cm} / \mathrm{g}$ \\
\hline 8 & Free Swell Index & $25 \%$ \\
\hline 9 & Optimum moisture content & $1.53 \mathrm{~g} / \mathrm{cc}$ \\
\hline 10 & Maximum dry density & $20 \mathrm{kPa}$ \\
\hline
\end{tabular}

Table 3: Chemical Composition of soft clay

\begin{tabular}{|c|c|c|}
\hline S.No & Description & Value \\
\hline 1 & $\mathrm{pH}$ Value & 4.21 \\
\hline 2 & Cation Exchange Capacity & $90 \mathrm{meq} / 100 \mathrm{~g}$ \\
\hline 3 & Organic Matter (\%) & 3.4 \\
\hline 4 & Calcium Carbonate (\%) & 0.0012 \\
\hline 5 & Iron Oxide (\%) & 2.0 \\
\hline 6 & Chlorides (\%) & 0.00022 \\
\hline 7 & Aluminium Oxide (\%) & 2.78 \\
\hline 8 & Total soluble solids (\%) & 0.98 \\
\hline 9 & Sulphates (\%) & \\
\hline
\end{tabular}

Table 4: Chemical Composition of Leachate

\begin{tabular}{|c|c|c|}
\hline S.No & Description & Value \\
\hline 1 & $\mathrm{pH}$ Value & 7.8 \\
\hline 2 & Conductivity $(\mathrm{milli} \mathrm{mhos} / \mathrm{cm})$ & 13.62 \\
\hline 3 & Chloride $(\mathrm{mg} / \mathrm{l})$ & 2569.92 \\
\hline 4 & Sulphate $(\mathrm{mg} / \mathrm{l})$ & 221.5 \\
\hline 5 & Nitrate $(\mathrm{mg} / \mathrm{l})$ & 5 \\
\hline 6 & Phosphate $(\mathrm{mg} / \mathrm{l})$ & 600 \\
\hline 7 & Calcium $(\mathrm{mg} / \mathrm{l})$ & 1400 \\
\hline 8 & Magnesium $(\mathrm{mg} / \mathrm{l})$ & 224.6 \\
\hline 9 & Sodium $(\mathrm{mg} / \mathrm{l})$ & 454.3 \\
\hline 10 & Potassium $(\mathrm{mg} / \mathrm{l})$ & 32.5 \\
\hline 11 & Available Iron $(\mathrm{mg} / \mathrm{l})$ & 800 \\
\hline 12 & COD $(\mathrm{mg} / \mathrm{l})$ & \\
\hline
\end{tabular}

\section{Free Swell Index}

The free swell index values of soil decreases with increase in percentage of leachate as well as with increase in curing period because of decrease in thickness of double layer same as in case of liquid limit. The variation of free swell index with percentage of leachate is furnished in Fig. 5.

\section{Vane Shear Strength}

The shear strength values are not much affected with increasing percentage of leachate. Previous studies [8,5] have shown that only concentrated organic chemicals can attack compacted clay, effectively destroying the barrier characteristics of the liner material. The leachate used for the experimental work may be relatively less concentrated and show minimal decrease in shear strength. Variation of vane shear strength with different percentages of leachate for different curing periods is shown in Fig. 6. The changes in $\mathrm{pH}$, Free swell index and Vane shear strength values in leachate contaminated soils are given in Table 6.

Table 5: LL, PL and PI of Soft Clay Contaminated with Leachate at 10 and 40 Days of Curing Period

\begin{tabular}{|c|c|c|c|c|c|c|}
\hline Name of the Property & \multicolumn{2}{|c|}{ Liquid Limit (\%) } & \multicolumn{2}{c|}{ Plastic Limit (\%) } & \multicolumn{2}{c|}{ Plasticity Index (\%) } \\
\hline Days of Curing & $\mathbf{1 0}$ & $\mathbf{4 0}$ & $\mathbf{1 0}$ & $\mathbf{4 0}$ & $\mathbf{1 0}$ & $\mathbf{4 0}$ \\
\hline Soft Clay & 69 & 68 & 33 & 33 & 36 & 35 \\
\hline Clay + 10\% Leachate & 62 & 61 & 29 & 28 & 33 & 33 \\
\hline Clay + 20\% Leachate & 56 & 54 & 26 & 24 & 30 & 30 \\
\hline Clay + 40\% Leachate & 51 & 48 & 21 & 18 & 30 & 30 \\
\hline
\end{tabular}


Table 6: pH, FSI and Vane Shear Strength of Soft Clay Contaminated with Leachate at 10 and 40 Days of Curing Period

\begin{tabular}{|c|c|c|c|c|c|c|}
\hline Name of the Property & \multicolumn{2}{|c|}{$\mathbf{p H}$} & \multicolumn{2}{c|}{ Free Swell Index $\left(\mathbf{c m}^{\mathbf{3}} / \mathbf{g}\right)$} & \multicolumn{2}{c|}{ Vane Shear Strength $(\mathbf{k P a})$} \\
\hline Days of Curing & $\mathbf{1 0}$ & $\mathbf{4 0}$ & $\mathbf{1 0}$ & $\mathbf{4 0}$ & $\mathbf{1 0}$ & $\mathbf{4 0}$ \\
\hline Soft Clay & 4.2 & 4.2 & 2.0 & 2.0 & 20 & 20 \\
\hline Clay + 10\% Leachate & 4.8 & 4.9 & 2.0 & 1.95 & 19 & 19 \\
\hline Clay + 20\% Leachate & 5.2 & 5.4 & 1.9 & 1.8 & 19 & 18 \\
\hline Clay + 40\% Leachate & 5.6 & 6.1 & 1.75 & 1.6 & 18 & 16 \\
\hline
\end{tabular}

\section{Cation Exchange Capacity (CEC)}

The CEC of the soil is obtained as $90 \mathrm{meq} / 100 \mathrm{gms}$. A scan through literature indicates a value of potential CEC of 3 for Kaolinite, 150 for Illite, 100 for Montmorillonite and 20 for Chlorite. The X-ray diffraction pattern for the soil indicates the presence of Kaolinite, Chlorite and Illite-Montmorillonite mixture. Thus there is a good correlation between the experimental value of CEC and minerals identified.

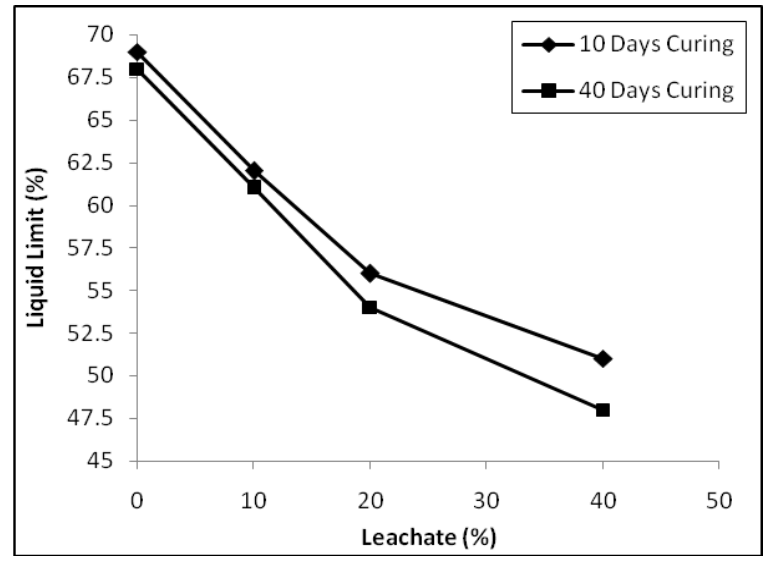

Fig. 1: Variation of Liquid Limit with Percentage of Leachate

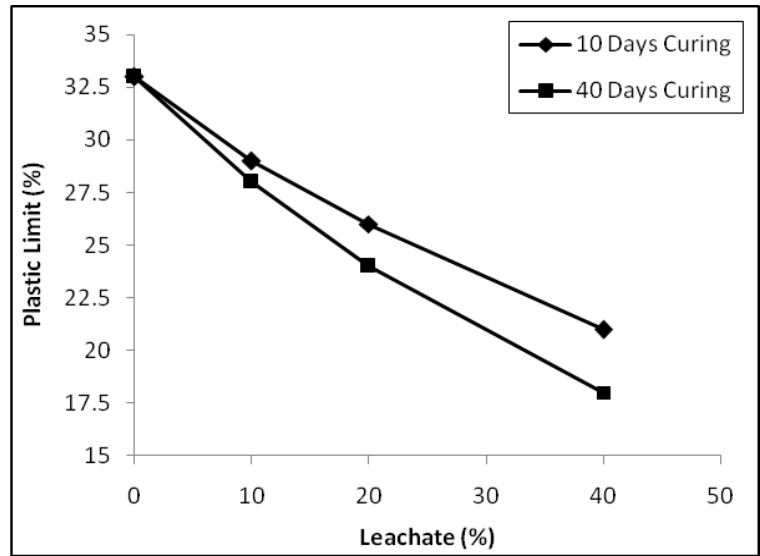

Fig. 2: Variation of Plastic Limit with Percentage of Leachate

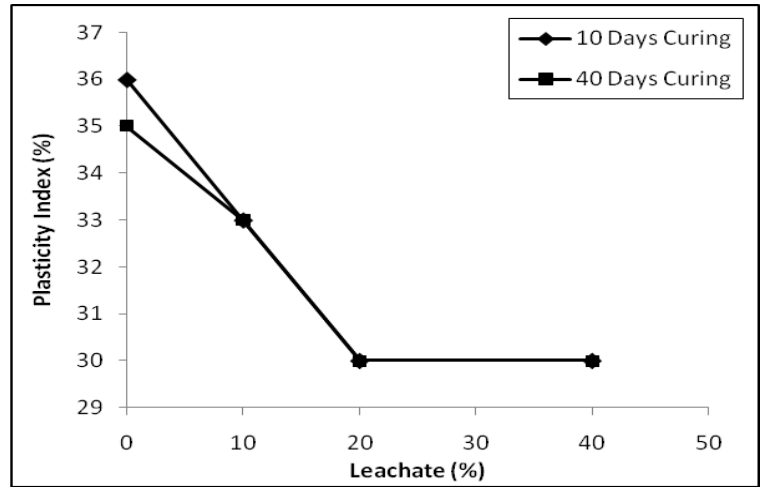

Fig. 3: Variation of Plasticity Index with Percentage of Leachate 


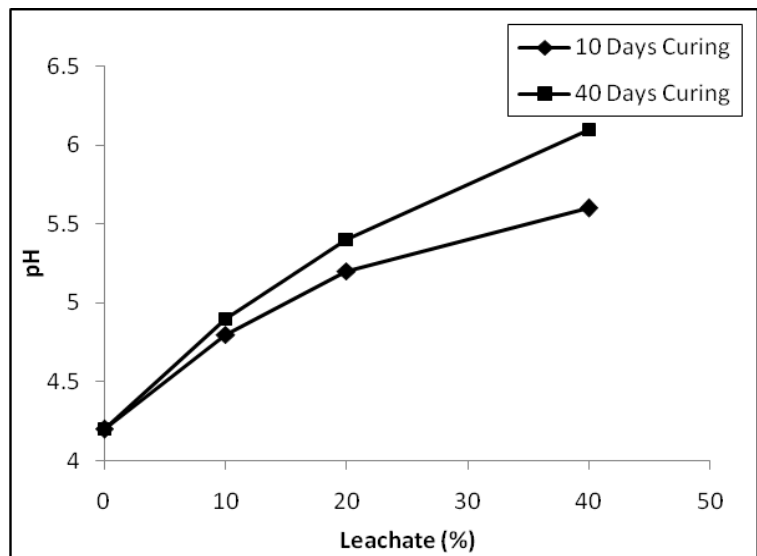

Fig. 4: Variation of $\mathrm{pH}$ with Percentage of Leachate

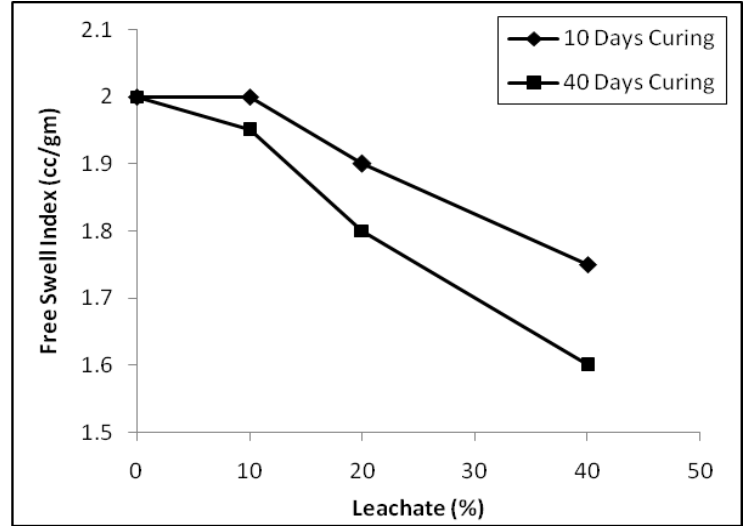

Fig. 5: Variation of Free Swell Index with Percentage of Leachate

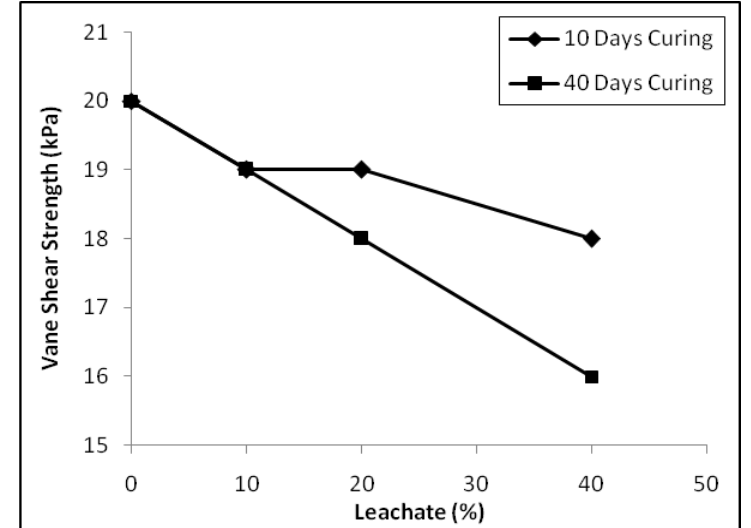

Fig. 6: Variation of Vane Shear Strength with Percentage of Leachate

\section{Mineralogy}

The peaks were noted according to the data given by Chao [9] for identifying the mineral phase using X-ray diffraction technique. The XRD study of the soft clay indicated that the soil is composed of various minerals of swelling and non-swelling type, but dominantly non-swelling Kaolinite. The diffraction analysis of soft clay with increasing percentage of leachate at the same curing period shows the formation of swelling group like Illite-Montmorillonite mixtures. There is a noticeable increase in the peak of Illite group mineral (Phlogopite) at $40 \%$ of leachate. The diffraction analysis of soft clay with increasing curing period with given leachate contamination shows the formation of non-swelling minerals like Microcline, Halite, Lepidolite etc. The peak of Illite group mineral (Muscovite), decreased at $40 \%$ of leachate when the curing period changes from 10 to 40 days. The XRD pattern of soft clay contaminated with $40 \%$ Leachate after 40 days curing are shown in Fig. 7.

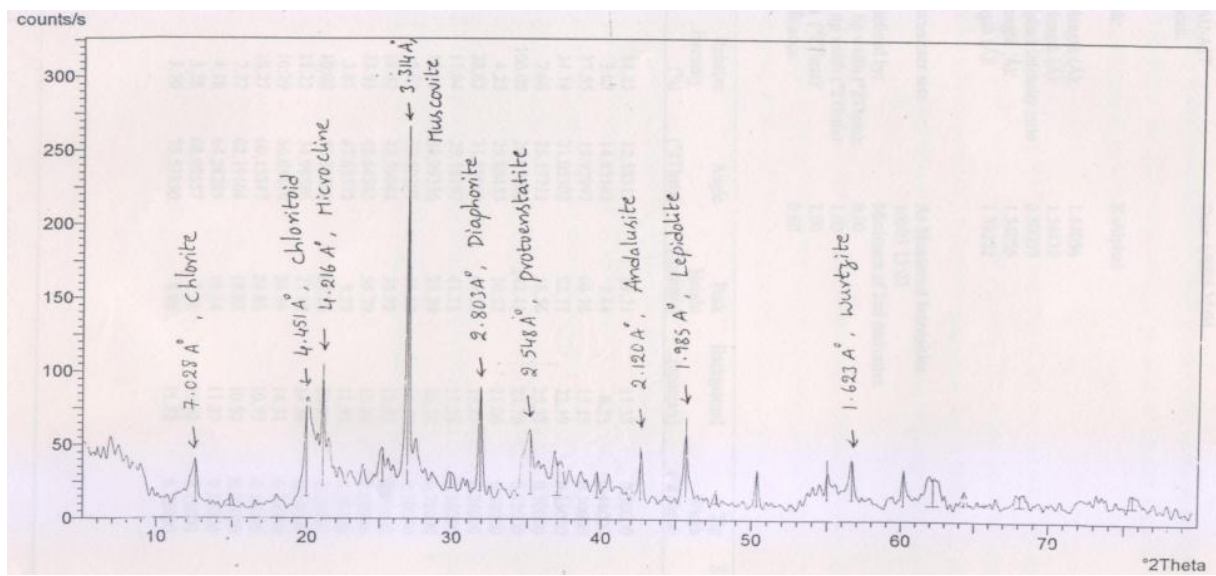

Fig. 7: XRD Pattern of $40 \%$ Leachate Contaminated Soft Clay after 40 Days Curing 


\section{Microstructure}

Out of many techniques available for study of soil fabric, Scanning Electron Microscope (SEM) facilitates the direct observation of particles or fracture surfaces through soil sample with large depth of field. The micrographs of soft clay in natural dry state and after curing it at OMC for 10 days and 40 days shows the strong but incomplete preferred orientation with the probability of particles lying perpendicular to the stress distribution is noticed. The effect of curing is formation of voids increasing with increasing time. It can be noticed from the micrographs with increasing leachate for 10days curing that there is a formation of aggregates of various sizes and decreasing density and decreasing rigidity. Little connectivity between particles also can be noticed with increasing leachate content. At lower curing periods, it can be noticed that particles are grouped in flocs, which are themselves packed loosely. However, at higher curing periods the flocky nature still remains intact but the looseness of soil structure increases. The most noticeable thing in the micrographs is the absence of any sand sized particles and presence of more silt sized particles with certain clay particles. The SEM photograph of soft clay contaminated with $40 \%$ Leachate after 40 days curing are shown in Fig. 8.

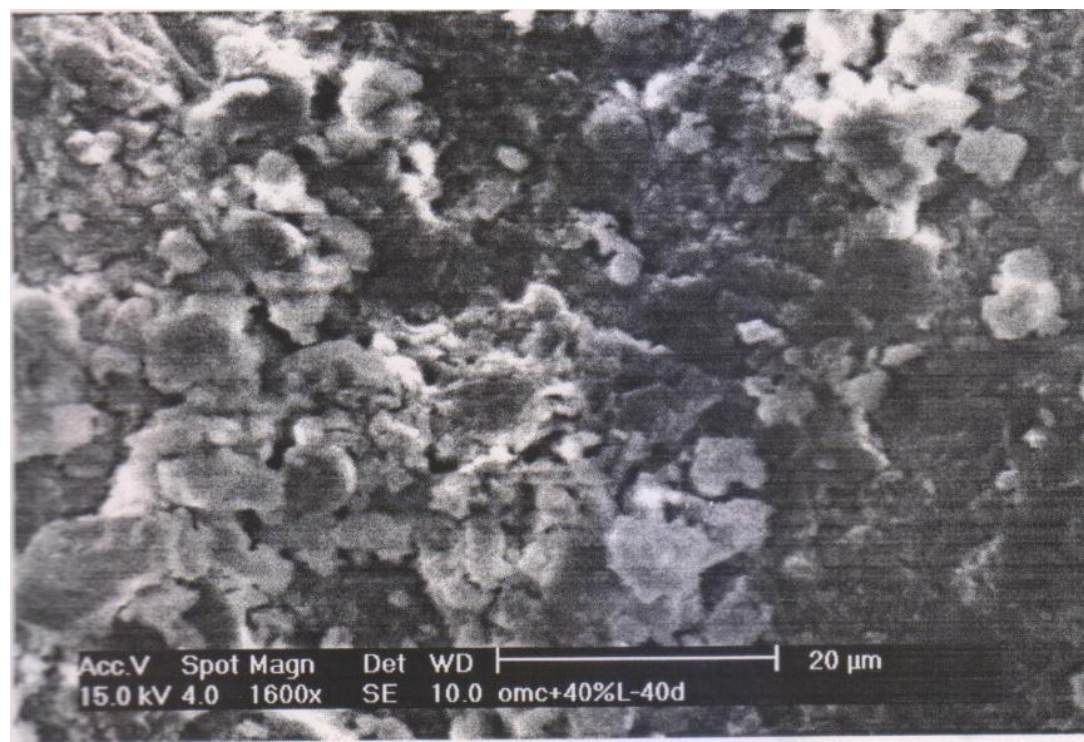

Fig. 8: SEM Photograph of $40 \%$ Leachate Contaminated Soft Clay after 40 Days Curing

\section{Conclusions}

- Ten soil samples are tested for their properties and suitability of soils for clay liners are decided depending on the clay content and plasticity index. Although most soils satisfy the stability criteria, the permeability in "True saturated" state for many soils requires some stabilizing agent like bentonite to satisfy the permeability criteria.

- The liquid limit and plasticity characteristics of the soft clay decreased due to the decreased thickness of double layer when exposed to leachate. The organic matter and oxides present in the soft clay are dissolved in leachate and are responsible for the decrease in values of Free swell index.

- Leachate shifts the $\mathrm{pH}$ value from acidic to alkaline, which increases the fertility of the soil useful for vegetation growth.

- The shear strength determined by laboratory vane is not much affected with either leachate interaction or on curing; this is attributed possibly to the lack of concentrated organic chemicals in the leachate.

- The diffraction analysis of soft clay contaminated with increasing percentages of leachate shows the formation of new minerals of Illite-Montmorillonite mixtures. With increasing percentage of leachate here is a noticeable increase in the peak of Illite group mineral. With increasing curing period, new minerals of Kaolinite and chlorite group are formed.

- With increasing percentage of leachate in soft clay, aggregates of various sizes with decreasing density and rigidity are formed, which are observed in scanning electron micrographs. At higher curing periods the looseness of soil structure increases. 


\section{References}

[1] Rama Rao. R., Sandhya Rani. R. and Krishna Rao. C. V. (2005), "Some Studies on Landfill Compacted Clay Liners- A Case Study", GEOPRACTICE-2005, National Conference on Case Studies in Geotechnical Engineering, July 25-26.

[2] Tovey. N. K and Wong. K. Y (1973), “The Preparation of Soils and other Geological Materials for the SEM", Proceedings of the International Symposium of Soil Structure, Gothenburg, Sweden, pp. 59-67.

[3] Sivapullaiah. P. V., Sridharan. A. and Stalin. V. K. (2000), "Hydraulic Conductivity of Bentonite-Sand Mixtures", Canadian Geotechnical Journal, Vol. 37, pp. 406-413.

[4] Mitchell. J. K., Hooper. D. R. and Campanella. R. G. (1965), "Permeability of Compacted Clay", Journal of Geotechnical Engineering, ASCE, Vol. 91, No. SM4, pp. 41-65.

[5] Gregory P. Broderick and David E. Daniel (1990), "Stabilizing Compacted Clay against Chemical Attack", Journal of Geotechnical Engineering, Vol. 116, No. 10, pp. 1549-1567.

[6] Nirmala Gnanapragasam, Barbana-Ann G. Lewis and Richard J. Finno (1995), "Microstructural Changes in Sand-Bentonite Soils when Exposed to Aniline", Journal of Geotechnical Engineering, ASCE, Vol. 121, No. 2, pp. 119-125.

[7] Fernandez. F. And Quigley. R. M. (1985), "Hydraulic Conductivity of Natural Clays Permeated with Simple Liquid Hydrocarbons", Canadian Geotechnical Journal, Vol. 22, No. 2, pp. 205-214.

[8] David E. Foreman and David E. Daniel (1986), "Permeation of Compacted Clay with Organic Chemicals", Journal of Geotechnical Engineering, Vol. 112, No. 7, pp. 669-681.

[9] Chao. G. Y. (1969), “XRD Peaks: Identification”, Department of Geology, Carleton University, Ottawa, Canada. 